\title{
OF SUBJECTS AND COWBOYS: FRONTIER AND HISTORY IN PEDRO MIR'S “COUNTERSONG TO WALT WHITMAN"
}

\author{
Christopher Conway
}

In 1893, Frederick JaCKson TuRner addressed the American Historical Association in Chicago with a paper titled "The Significance of the American Frontier in American History." "Up to our own day," Turner declared, "American history has been in a large degree the history of the colonization of the Great West." $\mathrm{He}$ argued that the frontier had provided the American people with a distinct identity, forged out of the challenges of taming the West:

American social development has been continually beginning over again on the frontier. This perennial rebirth, this fluidity of American life, this expansion westward with its new frontiers, its continuous touch with the simplicity of primitive society, furnish the forces dominating American character. (60)

Turner ended his address with a comparison that would prove to be prescient of American history to come: he compared the western frontier with the Mediterranean Sea that the Greeks sailed, discovering "new experiences, calling out new institutions and activities . .."(88). In effect, by the turn of the century, the United States had found maritime pathways through which to redefine its national character: by crossing the waters of the Caribbean and the Pacific, imperialism recast the romantic heroism of westward expansion into a more global context. The Spanish-American War of 1898-the dramatic culmination of a series of minor imperial "rehearsals"-effectively inaugurated modern U.S. imperialism. ${ }^{2}$

Pedro Mir, the "National" poet of the Dominican Republic, as well as a distinguished historian and novelist, engages the loss of the frontier and the birth of U.S. imperialism in his poem "Contracanto a Walt Whitman: Canto a Nosotros Mismos" ["Countersong to Walt Whitman: A Song of Ourselves"] (1952). Mir's representation of Whitman exalts the democratic potential of the U.S. and damns its imperial excesses through a retelling of U.S. history from the colonial period to the twentieth century. Like many other Latin American intellectuals, including José Martí and Pablo Neruda, Mir uses Whitman both to focus 
a critique of Anglo-American culture as well as to delineate the contours of a contestatory, pan-American identity. ${ }^{3}$

Divided into seventeen cantos, Mir's poem provides a historical materialist telos of the rise of capital and the birth of empire in the U.S. At the center of the poem is Mir's representation of Whitman's poetic utterance, a fully realized democratic space which acquires plenitude in the nineteenth century, but which is quickly depleted by monopoly capital at the turn of the century. The "countersong" proper begins at this juncture: by way of their resistance to empire, the oppressed masses of Latin America rush in to rescue Whitman from his capitalist captors and restore him to his originary, democratic glory. Thus, the fulfillment of liberty and justice for the Latin American victims of capital is also the fulfillment of Anglo-American identity in its original, "Whitmanian" definition. Mir charts these epochal changes in North and South America's shared history through an exploration of the subject status of the peoples of both Americas. The prominent use of the words yo, nosotros, mío, and nuestro (I, we, mine and ours) establishes the primacy of community and liberty for the definition of self. "Countersong" thus moves on two intertwined tracks: while charting epochal shifts according to a rudimentary materialist model, Mir narrates the changing status of the signifiers that define the subject status of a people.

One of the distinguishing characteristics of Mir's poem is his reinscription of the Anglo-American mythology of the lost, western frontier. Mir not only associates the democratic spirit of Whitman's voice with images of adventurers, goldpanners, cowboys and pioneers but also suggests that the fulfillment of Latin American freedom from empire entails the restoration of that "western" arcadia. Thus, while critiquing U.S. imperialism, the "Countersong" also reifies some of the very mythic categories upon which that imperialism was built. This essay will examine the contestatory dimensions of Mir's poem, most specifically his treatment of human subjectivity and his poetic periodization of U.S. history. Mir's treatment of the "frontier," which may be read with and against Turner's "frontier thesis," will provide insight into some of the instabilities in the text. I will argue that Mir's underlying, structuralist periodization of U.S. history leads him to alter the imperial definition of the "frontier" as well as to preserve its mythical, heroic stature.

Pedro Mir's originary, Anglo-American "I," which he associates with the Whitmanian poetic utterance, signifies the richness of a self that is able to apprehend itself and its world, taking full possession of it in an expansive and generous moment of connection. Central to this fulfillment is collectivity. Whitman's voice is a utopic space through which the Anglo-American people recognize themselves as such, acquiring identity through the very physicality of their existence and work. When Whitman says "I," the people come to know themselves: 
y el pescador se comprendió en su capa

y el cazador se oyó en mitad de su disparo

y el leñador se conoció en su hacha

y el labriego en su siembra y el lavador

de oro en su semblante amarillo sobre el agua

[and the fisherman understood himself in his slicker and the hunter heard himself in the midst of this gunshot and the woodcutter recognized himself in his axe and the farmer in his freshly sown field and the gold panner in his yellow reflection on the water $]^{4}$

All of the above characters are whole subjects whose work is presented as harmoniously joined to them. Mir goes on to show that this connectedness to oneself is the way in which individual subjects come to know each other and constitute themselves as a collective subject: "Y el pueblo entero se miraba a sí mismo / cuando escuchaba la palabra / yo ..." ["And all the people saw themselves / when they heard the word / I ...."] (68-69).

Whereas Whitman's originary voice was the spark of fusion and life, of freedom and movement for peoples completed as subjects, the gluttonous "I" of the capitalist initiates a moment of violence and division. This "I" belongs to Mr. Babbitt and Wall Street, referents which are fleetingly, though very emphatically, noted in the text. Babbitt's "I" is associated with coin currency and monopoly capital, an impersonal and standardized system that alienates the U.S. from itself while at the same time unleashing imperialism. The Whitmanian "I" is presented as a kind of capital quantity of democratic subjectivity that has been locked up in the coffers of Wall Street, separating the people from themselves:

Tú,

que en medio de la noche dijiste

Yo, Walt Whitman, un cosmos,

un hijo de Manhattan

y un pueblo entero se descubrió en tu lengua

y se lanzó de lleno a construir su casa,

hoy,

que ha perdido su casa,

...

hoy no te reconoce

desgarrado Walt Whitman ...

[You,

who in the middle of the night said,

I, Walt Whitman, a kosmos

of Manhattan the son

and an entire people discovered themselves in your tongue

and all rushed full tilt into building their house,

today, 
when they have lost their house

today the people do not recognize you

tattered Walt Whitman. .. .] (84-85)

In contrast to the previous evocation of pre-capitalist workers in intimate, physical communion with their own work, the poem presents the capitalist reality with images of objects that have been extricated from the hands that produced them: "Atravesad las fábricas de muebles y automóviles, los muelles, / las minas, las casas de apartamientos, los ascensores celestiales / . . . / Inútilmente. / No encontraréis el limpio acento de la palabra / yo." ["Go through the furniture and automobile plants, the docks, / the mines, the apartment houses, the celestial elevators, / . . . / No use. / You will not find the pure sound of the word / I"] (74-75). Whereas earlier Whitman had been presented as a guitar through which the people acquired a sense of self, the capitalist moment is represented with a spiritless piano, a telephone, a phonograph, a loudspeaker and a violin in which the "flawless sound / of the word / I" ["el acento sin mancha / de la palabra / yo"] (74-75) is silent and absent:

buscad un piano oscuro, revolved las cuerdas, los martillos, el teclado, rompedle el arpa silenciosa y tiradla sobre los últimos raíles de la madrugada . . .

Quebrad un teléfono y un disco de baquelita, arrancadle los alambres a un altoparlante nocturno, sacad al sol alma de un violín Stradivarius . . . Inútilmente.

[look for an obscure piano, pull apart the chords the hammers, the keyboard, break its silent harp and cast it upon the rails of the dawn ...

...

Smash a telephone and a phonograph record, tear out the wires from a loudspeaker at night, take the soul of a Stradivarius out into the sun ... No use.] (74-75)

Mir sees this cold, hard, capitalist "I" manifesting itself in Latin American puppet dictators, and in the bloodied cogs of imperial exploitation, describing it as Whitman's "old song turned into the song of force" ["canción antigua convertida en razón de fuerza"] (80-81). It is against this backdrop of the loss of an originary, democratic Anglo-American "I" that the poem introduces nosotros, the collective "we" of Latin America. This collective subject struggles to free itself from the oppression of the Whitmanian "I" that has been taken hostage by Babbitt's Wall Street world of signification. 
In addition to its anti-imperialist appropriation of Whitman, and the sustained attention to the question of subjectivity, "Countersong to Walt Whitman" is an anti-foundational narrative that decenters AngloAmerica's myth of Manifest Destiny and places the glorious culmination of Anglo-American history in the hands of the oppressed masses of Latin America. Mir's historical model is the structure through which the themes of Whitman, Babbitt, and the self and language are made legible. The periodization begins in a pre-linguistic and prehistorical space populated by the animated features of a fecund landscape at play with itself, unfettered by the limitations of signs: "Hubo una vez un territorio puro. / Árboles y terrones sin rúbricas ni alambres. / Hubo una vez un territorio sin tacha" ["There once was a pure territory. / Trees and land without rubric or wire. / There once was a territory without mark"] (48-49). References to plains that gallop like buffalo, hills that move like goats and gazelles, and rocks birthing diamonds, suggest that this is an originary time predating the division of nature into categories, species and types. Mir also notes that this is a time without a trace of a historically transitive human subjectivity, which he defines with the word "mío" ["mine"] (50-51).

History proper begins in the colonial period, as a constricted fluttering, a limited coming into being of a sense of being. The operative images are constriction and darkness, and the timid tempo of fear before the Law: "el yo que iba a decirla estaba allí / pero cogido / como un pez / en su red de costillas. / Estaba / pero interno, pero adusto y confinado ..." ["the I that was going to say it was there / but caught / like a fish / in its net of ribs. / He was there / but inside, austere and pent up ..."] (54-55). The Independence that follows this period is a centrifugal spillage of freedoms, of light depleting the confining darkness of the Law (56-57). Mir populates this vision of an originary, democratic U.S. by unleashing idyllic images of nineteenth-century Americana, as culled from the populist repertoire and tonalities of Whitman's own poetry (youths, country boys, rowdies, farmers).

\footnotetext{
de novias y donceles, de bravos y labriegos, de rudos mozalbetes camino del riachuelo, de guapos con espuelas y mozas con sonrisas, de marchas presurosas de seres infinitos, de trenzas o sombreros...
}

[of sweethearts and youths, of brave souls and farmers, of country boys walking to creeks, of rowdies wearing spurs and maidens wearing smiles, of the hurried marches of numberless beings,

of tresses or hats ... .] (58-59) 
This initial, democratic moment is pure and free, unmarred by violence, aggression and possession.

Mir introduces an inexorable movement of expansion, and problematizes his idyllic construct of American democracy with images of busy, civilizing activity: fighting Indians, unfurling paths and roadways, and urban development (59-60). He establishes the imperative of expansion and its violent nature by equating it with the violation of roads and with the prerogative of the strong. This coming-into-being across the land, through it and over it, is also presented as the birth of a set of narratives and signs of the self, which begin to swallow up the land and make it as intimately one's own as language itself. The cast of characters earlier sketched as vague indicators of motion and joy is turned into a set of recognizable cultural types that specify the economic, cultural, religious, and mythological components of U.S. expansion (cowboys, adventurers, preachers, pioneers, gold panners, etc.). Then, Mir delineates their possessive relationship to the land and to existence itself:

y la estatura de la cordillera yo

y las espigas de la llanura yo

y el resplandor de los arados yo

y las orillas de los arroyos yo

y el corazón de la amatista yo

[and the heights of the mountain range I

and the wheat of the prairie I

and the glint of the plows I

and the banks of the streams I

and the heart of the amethyst I] (62-63)

The American self, that sign that says "I," is here shown as absorbing landscape into the very heart of language. Possession is a physical act, but also a form of self-knowledge, which prescribes an identity through which a reality is created by human activity. Filled with the plentiful "I," Mir presents westward expansion as a measure of the tremendous stature of the subject's self-confidence and definition of self.

The birth of imperialism is a moment of loss, however. The exalted richness of the Anglo-American self that Mir has emphasized is depleted when "the Yankee clipper / began to sail the wild seas" ["Por los mares bravíos / empezó a transitar el clíper yanqui”]. The self is presented as a "revolving of all mirrors / around a single image" ["rotación de todos los espejos / sobre una sola imagen"] (64-65), suggesting that as the expansionist imperative of Manifest Destiny widens Anglo-America's sphere of influence in a global context, so the sense of self becomes increasingly alienated. ${ }^{5}$ Mir follows this movement with the moment of monopoly capital, which steals access to the word "mine" and "I." This is the era of Babbitt and Wall Street, and Mir deploys the imagery of 
coin currency, spiritless commodities, and the imperial plunder of raw materials to convey the corruption of the Whitmanian, democratic ideal. Mir puts the following words in Babbitt's mouth: "Traedme todos esos pueblos en azúcar, en nitrato, / en estaño, en petróleo, en bananas, / en almíbar / traedme todos esos pueblos." ["Bring me all those nations in sugar, in nitrate, / in tin, in oil, in bananas, / in syrup / bring me all those nations"] (76-77).

Mir introduces the idea of a historical shift from the Anglo-American imperial age, dominated by the corrupt "I," to a Hispanic democratic age, to be defined by the pronoun "we." The Walt Whitman that had been a clear pool in which the U.S. had seen itself with a pure, communal visage, has been torn asunder and replaced with alienation, oppression and empire. Upon this stage Latin America enters to begin the "countersong" and the "song of ourselves." The anti-imperialist, emancipatory struggle is continental, and it seeks to restore Whitman to his original meaning and to restore to the North American continent its original meaning:

Aquí estamos

salvando tus colinas de Vermont, tus selvas de Maine, el zumo y la fragancia de tu tierra, tus guapos con espuelas, tus mozas con sonrisas, tus rudos mozalbetes camino del riachuelo.

[Here we are

saving your hills of Vermont, your woods of Maine, the sap and fragrance of your land, your spurred rowdies, your smiling maidens, your country boys walking to creeks.] (98-99)

Mir is arguing for the restoration of the utopic world of Whitman's poetry. Whitman's America is the lost origin that the combative nosotros (ourselves) struggles to restore; inside of that America there is freedom and freshness and sweetness, selfhood and community, in a time before coin. Mir suggests that the U.S. was only itself for a brief shining moment, and that only Latin America, from its peripheral position and through its impassioned nosotros, can restore it to itself.

Pedro Mir's poem is invested in preserving the "frontier" as an operative category of Anglo and Latin American identity. As stated earlier, Mir marks the corruption of the Whitmanian "I" with the birth of monopoly capital and the rule of Babbitt and Wall Street. In this capitalist word of circulating coin, spilling out of national borders in imperial practices, the fresh face of Anglo-American democracy represented by Whitman's poetry of the people is lost. Mir represents this loss in terms of the end of an idyllic frontier life: 
surgieron entonces los Bancos, los Trusts, los monopolios,

las Corporaciones ... Y Y, cuando nadie lo supo,

fueron a dar allí la cara de la niña y el corazón

del aventurero y las cabriolas del cow-boy y los anhelos

del pioneer ... y todo aquel inmenso territorio

empezó a circular por las cajas de los Bancos. . . .

[the Banks, the Trusts, the monopolies,

the Corporations all sprang up ... And, when nobody knew it, the face of the little girl and the heart

of the adventurer and the cavorting of the cowboy and the longings

of the pioneer ended up there ... and that whole immense land

began to circulate through the vaults of the Banks. . . .] (71-73)

The protagonists of this free world, lost to the present of capitalist exchange, prominently appear throughout the poem as symbols of freedom. Cowboys, pioneers, and farmers are in turn associated with innocence destroyed, as evidenced by their association with a little girl's face. Mir's description, in the last canto of the poem, of a militarized Whitman crushing "the temples of little girls" ["las sienes de las niñas"] (96-97) reinforces this association of feminine innocence with a vanishing frontier. Further, in his treatment of the era prior to empire, Mir celebrates the comings and goings of rustic types, such as farmers, "country boys walking to creeks" ["rudos mozalbetes camino del riachuelo"] and "rowdies wearing spurs" ["guapos con espuelas"] (58-59), all of which will be rescued and restored through Latin America's emancipatory project. In fact, the Latin American freedom fighters are identified as "the pioneers of today," rallying to rescue their people by restoring an Anglo-American, mythological world populated with benevolent adventurers, homesteaders, and cowboys (98-99).

Through the image of a tabula rasa that is inscribed by the historical, westward march of the American people, Frederick Jackson Turner's 1893 study suggested that the frontier had been depleted from the inside out, and that its existence had been constitutive of the very logic of U.S. history. The eclipse of the frontier was not the death knell of history and national potential, however, but merely the "closing of the first period of American history" (88). By ending his essay with the image of the Mediterranean, and with the concept of historical "periods," Turner paved the way for interpretations that would relocate the frontier outside of the nation's borders and as the threshold upon which a second "period" of glorious American history would be possible. ${ }^{6}$ Indeed, the frontier as a place where Anglo-American, masculine heroism found its measure and its glory was relocated at the turn of the century with U.S. interventions in Cuba, the Philippines, and Central America. ${ }^{7}$ Though the "Countersong" concurs with Turner's "frontier thesis" in viewing 
the frontier as constitutive of U.S. identity, Mir's frontier is not a principle of ever-increasing expansion but a principle of spiritual equilibrium in which a people find freedom and solidarity. Although it is vaguely suggested that the arrival of monopoly capital is related to westward expansion, the insistence throughout the poem on presenting the protagonists of a mythological frontier as victims of capital suggests a more limited view of the end of the frontier, which is eclipsed from the outside in rather than from the inside out, as Turner argues. Mir circumscribes the North American "west" to a specific, lost time and describes its historical arc as fundamentally discontinuous with monopoly capital, urban development, and empire. What has occurred is a subversion of the spatial and temporal locators of Manifest Destiny's concept of "frontier"; as a lost Eden, Mir's frontier represents the hope of return, a shrinking back into the interior of the nation's borders, and to a mythic, democratic past represented by Whitman's voice. What's more, Mir's "frontier" thesis also decenters the U.S. as a superpower with historical agency, transferring the burden of epochal transformation from Babbitt and his gunboats to the confident and multitudinous arms of the Hispanic peoples of Latin America.

Mir's rewriting of the myth of Turner's "frontier" is not without tension, however. By privileging Whitman's poetry as the source for a utopic vision of Anglo-American identity, the "Countersong" elides the problem of race in the history of the U.S. and echoes the dominant themes and images of Anglo-American nationalism and colonial ideology. The American Indian wars are mentioned in an offhand manner, and slavery is not touched upon at all. Although Mir racializes the problematic of resistance to imperialism, populating Latin America's "we" with Africans, Asians, mestizos and indigenous peoples, the idyllic America that this pan-racial collective subject struggles to rescue and restore to its Whitmanian glory is an Anglo-American nation devoid of racial divisions, and whose protagonists are markedly white in their "wild west" connotation: gold panners, pioneers, cowboys, preachers, hunters, lumberjacks, etc. They constitute a collective subject cast in the role of victims to capital, and so their status as one mythic people remains intact. The erasure of the category of race in favor of a structural and periodizing long duree approach to history (rural arcadia to capital to empire) is significant here, for it promotes a classless, agrarian and ultimately ahistorical vision of the Anglo-American past that makes an affirmative mythology of Anglo-American origins possible. Mir's commitment to telling the story of the origins of empire without discarding a positive vision of the democratic potential of the U.S. leads him to gloss over race in favor of a periodizing metanarrative that will allow both critique and panegyric.

"Countersong to Walt Whitman" is indeed a critique of imperialism, but unlike so many other texts produced in twentieth-century Latin 
American letters, its focus is committed to narrating the story of the center. Although combative, Mir's poem does not cast Anglo-America as an essentially antagonistic force but rather as a paragon of democracy taken hostage by monopoly capital. The end of empire, through the resistance of Latin America, is not a struggle for hegemony between two geographic powers but a struggle between absolutes that will result in a post-national and post-capitalist order. The ideal of the Americas united by a shared ethic will be consummated under the freedoms enshrined by an originary U.S. and given full voice by the poetry of Whitman.

Mir's poem is a part of a deeply entrenched "Whitman tradition" in Latin American literature, but its importance should not be reduced to literary history's genealogical or serialized paradigms. Mir's poem presents a complex analysis of the imperial experience, both in the center and on the periphery. It is a testament to the artistry of the poem that Mir locates the experience of empire in the very heart of language, in the pronouns that are used to designate the intimate conditions of social existence and its relationship to the painful trials of historical processes. Mir's remythologizing of the American West, however, raises some intriguing questions about the poem's coherence as an anti-imperialist indictment of the U.S. While pursuing a materialist, teleological narrative on one level, Mir reifies some of the key, mythic categories of the ideology of Manifest Destiny. As a prehistorical time that precedes the launching of "History" through capitalism and its attendant alienation and imperialism, Mir's Anglo-American frontier is abstracted out of the logic of U.S. development and transformed into a principle of Edenic democracy. It is from this new symbolic location that the frontier thesis is rewritten as a principle of resistance to empire, as the promised land of the Latin American victims of empire.

\section{University of Texas, Arlington}

\section{NOTES}

1 Frederick Jackson Turner, History, Frontier and Section: Three Essays by Frederick fackson Turner (Albuquerque: University of New Mexico Press, 1993), 59.

2 Although the Spanish-American War was preceded by other interventions in Latin America, and to a lesser degree Asia and Africa, the war tested a fully realized imperial policy. Unlike prior interventions, the conflict was predicated on an awareness that global expansion was key for prosperity at home. Such ideas were not new, but economic depression and concerns over losing a stake in Asia to European rivals encouraged the U.S. to adopt an expansionist foreign policy at the turn of the century.

3 For an account of the Whitman tradition in Latin America, see Fernando Alegría, "Whitman in Spain and Latin America," in Gay Wilson Allen and Ed Folsom, eds., Walt Whitman and the World (Iowa City: University of Iowa Press, 1995), 71-127.

4 Pedro Mir, Countersong to Walt Whitman and Other Poems, trans. Jonathan Cohen and Donald Walsh (Washington: Azul Editions, 1993), 66-67. 
5 This interpretation is supported by the following canto (9), in which Mir portrays Whitman as a kind of mirror in which the people come to know themselves as a people: "Porque / ¿qué ha sido un gran poeta indeclinable / sino un estanque límpido / donde un pueblo descubre su perfecto / semblante?" ["For / what has a great undeniable poet been / but a crystal-clear pool / where a people discover their perfect likeness?"] (66$67)$.

6 In an 1896 article for Atlantic Monthly, titled "The Problem of the West," Turner explicitly made the connection between frontier and outward expansion to "outlying islands and adjoining countries." See Walter L. Williams, "United States Indian Policy and the Debate over Philippine Annexation: Implications for the Origins of American Imperialism," The fournal of American History 66 (March 1980), 817.

7 See Christine Bold's "The Rough Riders at Home and Abroad: Cody, Roosevelt, Remington and the Imperialist Hero," The Canadian Review of American Studies 18 (Fall 1987), and Richard Slotkin's "Buffalo Bill's 'Wild West' and the Mythologization of the American Empire," in The Cultures of United States Imperialism, ed. Amy Kaplan and Donald Pease (Durham and London: Duke University Press, 1993). Bold and Slotkin demonstrate how "Buffalo Bill's Wild West" show merged frontier and imperial themes into a single, unified narrative of the Anglo-American self. Further, as Walter Williams has noted, American Indian policies of the nineteenth century prefigured the arguments for U.S. colonialism toward the Philippines (831). 